\title{
Management and retrospective analysis of tumors and tumor-like lesions localized in the talus
}

\author{
Yaman Karakoç, MD(D), Coşkun Ulucaköy, MD (i) \\ Department of Orthopedics and Traumatology, Dr. Abdurrahman Yurtaslan Oncology Training and Research Hospital, Ankara, Turkey
}

Bone tumors of the foot constitute $3 \%$ of all bone tumors while talus-localized bone tumors constitute 8 to $23 \%$ of foot bone tumors. ${ }^{[1]}$ Tumorlike lesions of bone are lesions having appearance and cytogenetic characteristics of neoplasm while their clinical behavior supports a non-neoplastic nature. Significance of the tumor-like bony lesions is that they are very common and their radiological appearance mimics that of true bone tumors including malignant lesions. There are no definite guidelines available for their management. ${ }^{[2]}$

Tumor cells do not settle in all bones at the same rate, indicating that tumor cell seeding is not suspect and/or soil within different bones is not suitable for tumor growth. For example, tumors are often found in bones rich in red marrow and trabecular bone, such as the vertebrae, ribs, pelvis and ends of long bones, but rarely occur in the bones of the hands or feet. ${ }^{[3]}$ More than half of the talar surface of the talus is covered with articular cartilage. Most of the

Received: September 03, 2020

Accepted: October 21, 2020

Published online: January 06, 2021

Correspondence: Coşkun Ulucaköy, MD. SBÜ Dr. Abdurrahman Yurtaslan Onkoloji Eğitim ve Araştırma Hastanesi Ortopedi ve Travmatoloji Kliniği, 06105 Yenimahalle, Ankara, Türkiye.

E-mail: coskunulucakoy@gmail.com

Dol: $10.5606 /$ ehc. 2021.78769

Citation: Karakoç Y, Ulucaköy C. Management and retrospective analysis of tumors and tumor-like lesions localized in the talus. Jt Dis Relat Surg 2021;32(1):218-223.

(C2021 All right reserved by the Turkish Joint Diseases Foundation

This is an open access article under the terms of the Creative Commons Attribution-NonCommercial License, which permits use, distribution and reproduction in any medium, provided the original work is properly cited and is not used for commercial purposes (http://creativecommons.org/licenses/by-nc/4.0/).

\section{ABSTRACT}

Objectives: This study aims to investigate the characterization and follow-up results of tumors and tumor-like lesions in the talus.

Patients and methods: Twenty-one patients ( 15 males, 6 females; mean age: $31.6 \pm 17$ years; range, 4 to 67 years) with benign and malignant tumors or tumor-like lesions in the talus region treated and followed in our clinic between January 2007 and January 2019 were evaluated retrospectively. Radiological, pathological, surgical, and demographic features were scanned from the database.

Results: Patients were followed for mean $80 \pm 45.1$ (range, 25 to 156) months. The most common complaint was pain and antalgic gait. Benign bone tumors were found in $15(71 \%)$ of 21 patients, while tumor-like lesions (two intraosseous ganglia, osteomyelitis, and bone infarction) were found in four patients. The remaining two were patients with lung and bladder cancer metastasis. Lesion size was mean $2.1 \pm 0.5$ (range, 1.1 to 3.3 ) $\mathrm{cm}$. Recurrence developed in $14.3 \%(n=3)$ of the patients during follow-up.

Conclusion: The talus is a rare location for tumors; however, benign and malignant tumors and tumor-like lesions may be localized in the talus.

Keywords: Bone tumor, surgical outcomes, talus.

talar body receives its blood in a retrograde fashion (distal to proximal) through anastomosis around the talar neck. Due to this, talar body is susceptible to avascular necrosis. The talus offers a unique anatomic setting and presents unusual problems of surgical management with avoidance of recurrence, fracture, avascular necrosis, and restoration of function. ${ }^{[1,2]}$

Tumor-like lesions are non-neoplastic bone lesions and are relatively common. They are lesions that radiologically, morphologically, and histologically mimic bone tumors. Intraosseous ganglia, non-ossifying fibroma, fibrous dysplasia, osteomyelitis, and bone infarction are among the most common tumor-like lesions. ${ }^{[4]}$ The talus may involve primary tumors, tumor-like lesions, and metastases, but the talus is a rare location for tumors. ${ }^{[2,4]}$ There are case reports about talus localization in the literature, 
while studies on talus-localized tumors are limited. Therefore, in this study, we aimed to investigate the characterization and follow-up results of tumors and tumor-like lesions in the talus.

\section{PATIENTS AND METHODS}

Twenty-one patients ( 15 males, 6 females; mean age $31.6 \pm 17$ years; range, 4 to 67 years) with benign and malignant tumors or tumor-like lesions in the talus region treated and followed in Dr. Abdurrahman Yurtaslan Oncology Training and Research Hospital between January 2007 and January 2019 were evaluated retrospectively. Radiological, pathological, surgical, and demographic features were scanned from the database. Patients who were operated for a tumor and tumor-like lesion localized in the talus and whose pathological diagnosis was confirmed were included in the study, while patients with osteochondral defects or post-traumatic cysts in their ankle and whose archive information could not be reached were excluded. The study patients were divided into two groups in order to compare them according to age and size. The study protocol was approved by the Dr. Abdurrahman Yurtaslan Oncology Training and Research Hospital Ethics Committee (number 2020-08/766). A written informed consent was obtained from each patient. The study was conducted in accordance with the principles of the Declaration of Helsinki.

\section{Statistical analysis}

Statistical analysis was performed using the IBM SPSS version 22.0 software (IBM Corp., Armonk, NY, USA). In statistical analysis, categorical variables were given as numbers and percentages and continuous variables were presented with mean \pm standard deviation and median (min-max) for descriptive analyses. Chi-square tests were used for comparison of categorical variables between groups. The conformity of continuous variables to normal distribution was evaluated using visual (histogram and probability graphs) and analytical methods (Kolmogorov-Smirnov/Shapiro-Wilk tests). Normality analysis revealed that all data sets were

\begin{tabular}{|c|c|c|c|c|c|c|}
\hline \multicolumn{7}{|c|}{$\begin{array}{c}\text { TABLE I } \\
\text { Characteristics of the patients }\end{array}$} \\
\hline & Age/Sex & Complaint & Size $(\mathrm{cm})$ & Treatment & Follow-up period (month) & Recurrence \\
\hline \multirow{3}{*}{ Giant cell tumor } & $32 / \mathrm{M}$ & Pain+antalgic gait & 2.2 & $\mathrm{C}+\mathrm{G}$ & 96 & Yes \\
\hline & 23/M & Pain+antalgic gait & 2.3 & $\mathrm{C}+\mathrm{G}$ & 109 & No \\
\hline & $31 / \mathrm{M}$ & Pain+antalgic gait & 2.5 & $\mathrm{C}+\mathrm{G}$ & 124 & No \\
\hline \multirow{3}{*}{ Aneurysmal bone cyst } & $37 / F$ & Pain+antalgic gait & 2.1 & $\mathrm{C}+\mathrm{G}$ & 88 & No \\
\hline & $17 / M$ & Pain+antalgic gait & 2.0 & $\mathrm{C}+\mathrm{G}$ & 27 & Yes \\
\hline & $28 / \mathrm{M}$ & Pain+antalgic gait & 2.0 & $\mathrm{C}+\mathrm{G}$ & 91 & No \\
\hline \multirow{3}{*}{ Chondroblastoma } & $17 / \mathrm{M}$ & Pain+antalgic gait & 2.4 & $\mathrm{C}+\mathrm{G}$ & 134 & Yes \\
\hline & $13 / F$ & Pain+antalgic gait & 2.4 & $\mathrm{C}+\mathrm{G}$ & 25 & No \\
\hline & 27/M & Pain+antalgic gait & 2.5 & $\mathrm{C}+\mathrm{G}$ & 31 & No \\
\hline \multirow{2}{*}{ Simple bone cyst } & $25 / F$ & Pain+antalgic gait & 1.8 & $\mathrm{C}+\mathrm{G}$ & 63 & No \\
\hline & $35 / \mathrm{M}$ & Pain+antalgic gait & 1.9 & $\mathrm{C}+\mathrm{G}$ & 114 & No \\
\hline \multirow{2}{*}{ Intraosseous ganglion } & $41 / F$ & Incidental & 1.4 & C & 156 & No \\
\hline & $42 / M$ & Incidental & 1.5 & $\mathrm{C}$ & 147 & No \\
\hline \multirow{2}{*}{ Osteochondroma } & $7 / M$ & Incidental & 2.0 & Excision & 146 & No \\
\hline & $67 / M$ & Pain+antalgic gait & 2.1 & Excision & 29 & No \\
\hline Osteoid osteoma & $13 / \mathrm{M}$ & Pain+antalgic gait & 1.1 & Excision & 41 & No \\
\hline Lipoma & $42 / \mathrm{M}$ & & 1.9 & $\mathrm{C}$ & 78 & No \\
\hline Bone infarction & $52 / F$ & Incidental & 2.1 & biopsy & 55 & No \\
\hline Osteomyelitis & $4 / F$ & Incidental & 1.9 & biopsy & 69 & No \\
\hline Bladder cancer metastasis & $53 / \mathrm{M}$ & Pain+antalgic gait & 3.1 & biopsy & 32 & No \\
\hline Lung cancer metastasis & $58 / \mathrm{M}$ & Pain+antalgic gait & 3.3 & biopsy & 25 & No \\
\hline
\end{tabular}




\begin{tabular}{|c|c|c|c|c|c|}
\hline \multicolumn{6}{|c|}{$\begin{array}{c}\text { TABLE II } \\
\text { Baseline demographics }(n=21)\end{array}$} \\
\hline Characteristic & $\mathrm{n}$ & $\%$ & Mean \pm SD & Median & Min-Max \\
\hline Age (year) & & & $31.6 \pm 17.0$ & 31 & $4-67$ \\
\hline \multicolumn{6}{|l|}{ Sex } \\
\hline Female & 6 & 28.6 & & & \\
\hline Male & 15 & 71.4 & & & \\
\hline \multicolumn{6}{|l|}{ Side } \\
\hline Right & 12 & 57.1 & & & \\
\hline Left & 9 & 42.9 & & & \\
\hline \multicolumn{6}{|l|}{ Type of lesions } \\
\hline Benign & 15 & 71.4 & & & \\
\hline Malignant & 2 & 9.5 & & & \\
\hline Tumor-like lesions & 4 & 19.0 & & & \\
\hline \multicolumn{6}{|l|}{ Surgical treatment } \\
\hline Excision & 3 & 14.3 & & & \\
\hline Biopsy & 4 & 19.0 & & & \\
\hline Curettage & 3 & 14.3 & & & \\
\hline Curettage + grafting & 11 & 52.4 & & & \\
\hline Follow-up period (months) & & & $80 \pm 45.1$ & 78 & $25-156$ \\
\hline Size $(\mathrm{cm})$ & & & $2.1 \pm 0.5$ & 2.1 & $1.1-3.3$ \\
\hline \multicolumn{6}{|l|}{ Recurrence } \\
\hline Yes & 3 & 14.3 & & & \\
\hline No & 18 & 85.7 & & & \\
\hline
\end{tabular}

not normally distributed. Mann-Whitney U test was used for comparison of data sets which were not normally distributed for the variables. Spearman's correlation was used to test the association between diameter and patients' ages. $\mathrm{P}<0.05$ was considered statistically significant.

\section{RESULTS}

Of the 21 patients, 15 had benign, two had malignant, and four had tumor-like lesions. The most common complaints were pain and antalgic gait $(71.4 \%)$. Of the patients, $71.4 \%(\mathrm{n}=15)$ were over 18 years of age. The demographic characteristics of patients with localized lesions of the talus are presented in Table I. While curettage + grafting was performed in 11 patients, only curettage was performed in three patients. Needle biopsy was performed in these patients beforehand. The lesion size was mean $2.1 \pm 0.5$ (range, 1.1 to 3.3 ) $\mathrm{cm}$. The mean follow-up period was $80 \pm 45.1$ (range, 25 to 156) months. Recurrence developed in $14.3 \%$ $(n=3)$ of the patients during follow-up (Table II). After recurrence, curettage, adjuvant phenol, and grafting were applied to all three patients. No significant correlation was found between age and tumor size $(\mathrm{r}=0.316, \mathrm{p}=0.164)$ (Table III).
In Table IV, some characteristics of the patients were compared according to age groups. The distribution of sex $(p=1.000)$, direction $(p=1.000)$, lesion type $(p=0.609)$, and recurrence rates $(p=0.184)$ of the groups were found to be similar. The median follow-up period of the patient group under 18 years of age was 55 (min 25-max 146) months, while the median follow-up period for the group over 18 years of age was 88 ( $\min 25$-max 156) months, with no statistically significant difference between the two groups $(p=0.559)$ (Table IV). When we divided the lesions into two groups according to the median size, there were 10 patients with lesions under $2.1 \mathrm{~cm}$ and 11 patients with lesions $2.1 \mathrm{~cm}$ and above. In Table $\mathrm{V}$, various demographic and clinical characteristics of the groups were compared according to the size. Age, sex, side, lesion type,

\begin{tabular}{|c|c|c|}
\hline \multicolumn{3}{|c|}{$\begin{array}{c}\text { TABLE III } \\
\text { Correlation between age and size }\end{array}$} \\
\hline & $r$ & $p$ \\
\hline Age & 0.316 & 0.164 \\
\hline
\end{tabular}




\begin{tabular}{|c|c|c|c|c|c|c|c|c|c|c|c|}
\hline \multirow[b]{3}{*}{ Parameters } & \multicolumn{10}{|c|}{$\begin{array}{l}\text { TABLE IV } \\
\text { Evaluation of age groups }\end{array}$} & \multirow[b]{3}{*}{$p$} \\
\hline & \multicolumn{5}{|c|}{$<18$ years $(n=6)$} & \multicolumn{5}{|c|}{$\geq 18$ years $(n=15)$} & \\
\hline & $\mathrm{n}$ & $\%$ & Mean $\pm S D$ & Median & Min-Max & $\mathrm{n}$ & $\%$ & Mean \pm SD & Median & Min-Max & \\
\hline Age (year) & & & $11.8 \pm 5.3$ & 13 & $4-17$ & & & $39.5 \pm 13$ & 37 & $23-67$ & $<0.001^{*}$ \\
\hline Sex & & & & & & & & & & & $1.000 \dagger$ \\
\hline Female & 2 & 33.3 & & & & 4 & 26.7 & & & & \\
\hline Male & 4 & 66.7 & & & & 11 & 73.3 & & & & \\
\hline Side & & & & & & & & & & & $1.000 \dagger$ \\
\hline Right & 3 & 50 & & & & 9 & 60 & & & & \\
\hline Left & 3 & 50 & & & & 6 & 40 & & & & \\
\hline Type of lesions & & & & & & & & & & & $0.609 \dagger$ \\
\hline Benign & 5 & 83.3 & & & & 10 & 66.7 & & & & \\
\hline Malignant & 0 & 0 & & & & 2 & 13.3 & & & & \\
\hline Tumor-like lesions & 1 & 16.7 & & & & 3 & 20 & & & & \\
\hline Follow-up period (months) & & & $73.7 \pm 53.7$ & 55 & $25-146$ & & & $82.5 \pm 42.9$ & 88 & $25-156$ & $0.559^{*}$ \\
\hline Size $(\mathrm{cm})$ & & & $2.0 \pm 0.5$ & 2 & $1.1-2.4$ & & & $2.2 \pm 0.5$ & 2.1 & $1.4-3.3$ & $0.532^{*}$ \\
\hline Recurrence & & & & & & & & & & & $0.184 \dagger$ \\
\hline Yes & 2 & 33.3 & & & & 1 & 6.7 & & & & \\
\hline No & 4 & 66.7 & & & & 14 & 93.3 & & & & \\
\hline
\end{tabular}

follow-up period, and recurrence conditions were similar between the groups $(p>0.05)$. Pre- and postoperative direct radiographs of the patient with aneurysmal bone cyst $(A B C)$ were presented in Figures 1 and 2, respectively. Two patients with bladder and lung cancer metastases died at 53 and 58 months, respectively. The remaining 19 patients are followed without any additional complications.

\begin{tabular}{|c|c|c|c|c|c|c|c|c|c|c|c|}
\hline \multirow[b]{3}{*}{ Parameters } & \multicolumn{10}{|c|}{$\begin{array}{c}\text { TABLE V } \\
\text { Evaluation of size groups }\end{array}$} & \multirow[b]{3}{*}{$p$} \\
\hline & \multicolumn{5}{|c|}{$<2.1 \mathrm{~cm}(\mathrm{n}=10)$} & \multicolumn{5}{|c|}{$\geq 2.1 \mathrm{~cm}(\mathrm{n}=11)$} & \\
\hline & $\mathrm{n}$ & $\%$ & Mean $\pm S D$ & Median & Min-Max & $\mathrm{n}$ & $\%$ & Mean $\pm S D$ & Median & Min-Max & \\
\hline Age (year) & & & $25.4 \pm 14.6$ & 26.5 & $4-42$ & & & $37.3 \pm 17.8$ & 32 & $13-67$ & $0.180^{*}$ \\
\hline Sex & & & & & & & & & & & $1.000 \dagger$ \\
\hline Female & 3 & 30 & & & & 3 & 27.3 & & & & \\
\hline Male & 7 & 70 & & & & 8 & 72.7 & & & & \\
\hline Side & & & & & & & & & & & $0.670 \dagger$ \\
\hline Right & 5 & 50 & & & & 7 & 63.6 & & & & \\
\hline Left & 5 & 50 & & & & 4 & 36.4 & & & & \\
\hline Type of lesions & & & & & & & & & & & $0.220 \dagger$ \\
\hline Benign & 7 & 70 & & & & 8 & 72.7 & & & & \\
\hline Malignant & 0 & 0 & & & & 2 & 18.2 & & & & \\
\hline Tumor-like lesions & 3 & 30 & & & & 1 & 9.1 & & & & \\
\hline Follow-up period (months) & & & $93.2 \pm 45.8$ & 84.5 & $27-156$ & & & $68 \pm 42.9$ & 55 & $25-134$ & $0.181^{*}$ \\
\hline Size (cm) & & & $1.8 \pm 0.53$ & 1.9 & $1.1-2$ & & & $2.5 \pm 0.4$ & 2.4 & 2.1-3.3 & $<0.001^{*}$ \\
\hline Recurrence & & & & & & & & & & & $1.000 \dagger$ \\
\hline Yes & 9 & 90 & & & & 9 & 81.8 & & & & \\
\hline No & 1 & 10 & & & & 2 & 18.2 & & & & \\
\hline
\end{tabular}



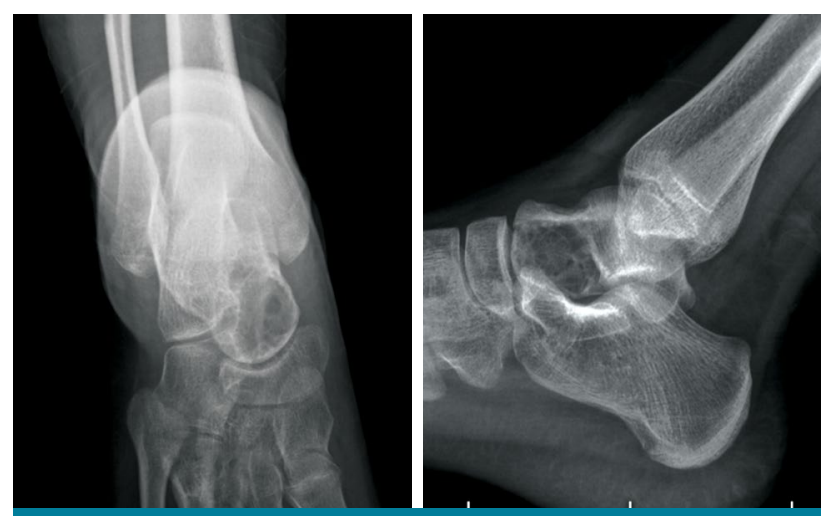

FIGURE 1. Preoperative X-ray image of a patient with aneurysmal bone cyst.

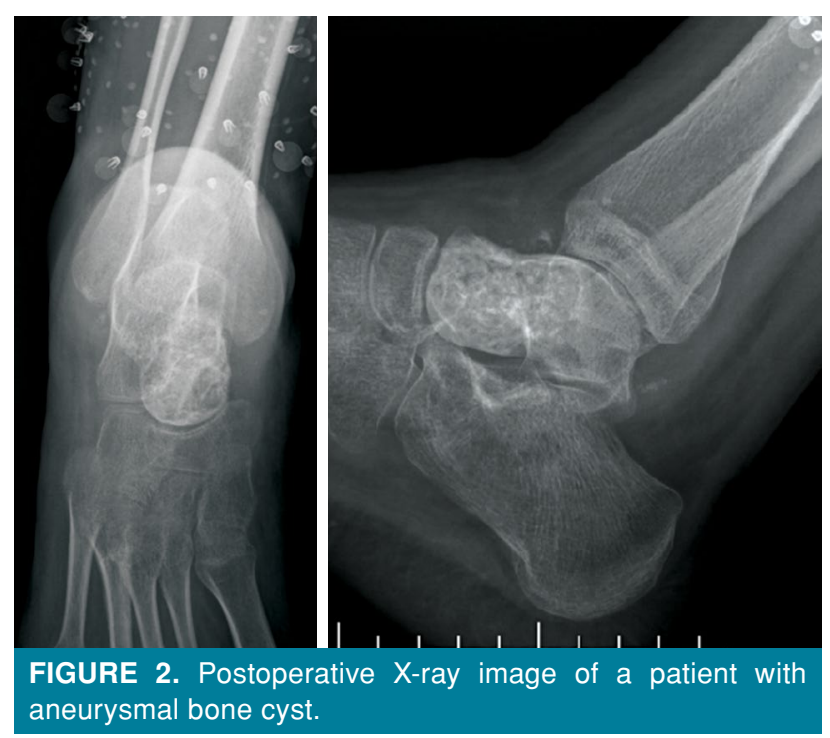

\section{DISCUSSION}

The talus is a rare location for tumors with its blood supply and anatomical features. The main finding of this study is that talus is a rare location for tumors, but benign and malignant tumors and tumor-like lesions may be localized in the talus.

The demographic information of the patients in this study was similar to the patients in previous studies in the literature. ${ }^{[5,6]}$ For example, the distribution of patients in this study included 15 males and 6 females (2.5:1). This ratio was 3:1 in a study conducted by Dhillon et al. ${ }^{[5]}$ Similarly, this ratio was 2.8:1 in a study of Bell et al. ${ }^{[6]}$ Benign tumors were more common in case series of talus and in previous studies. ${ }^{[1]}$ Similarly, benign tumors were predominant in this study. Fifteen (71.4\%) of the 21 cases presented were benign. Among the benign primary bone tumor pathologies described in this series, chondroblastoma, giant cell tumor (GCT), and $\mathrm{ABC}$ were the most common, and this finding was consistent with previous case reports in the literature. ${ }^{[5,6]}$

There were case reports in the literature about talus-localized $\mathrm{ABCs}{ }^{[7,8]}$ In the case report they presented, Sharma et al. ${ }^{[7]}$ applied curettage, adjuvant phenol, and grafts for the talus-localized $\mathrm{ABC}$ of a 20-year-old male patient and reported that there was no recurrence in the two-year follow-up. Differently, Vosoughi et al..$^{[8]}$ showed in their case report that arthrodesis is an option for recurrent talus $A B C$ at the age of 25 years. In our case series, the mean age of three $\mathrm{ABC}$ cases with talus localization was 27 (range, 17 to 37 ) and the mean follow-up period was 68 (range, 27 to 91 ) months. We applied curettage and grafts to all three patients, and recurrence occurred in one patient during follow-up. We applied curettage, adjuvant phenol, and grafts in post-recurrence treatment. There were no additional complications.

There were no studies about talus-localized GCT in the literature, but there were case reports. ${ }^{[9,10]}$ Sharma et al. ${ }^{[9]}$ reported total talectomy and arthrodesis after recurrence of a talus GCT of a 19-year-old male patient. Differently, El-Moatasem et al. ${ }^{[10]}$ did not observe recurrence for 40 months in patients who underwent curettage cryotherapy and grafting due to talus-localized GCT. In our case series, the mean age of three GCT cases localized in the talus was 28 (range, 23 to 32 ) and the mean follow-up period was 109 (range, 96 to 124) months. We applied curettage and grafts to all three patients. In a patient who developed recurrence after curettage grafting, we did not act as radical as Sharma et al. ${ }^{[9]}$ and we applied curettage phenol grafting. No recurrence was observed in our one-year follow-up.

Similar to GCT, talus localization is rare in chondroblastoma and there are only case reports in the literature. ${ }^{[11,12]}$ Ningegowda et al. ${ }^{[1]]}$ treated a 13-year-old male talus chondroblastoma patient with curettage and grafting and did not observe recurrence during follow-up. Similarly, Zhang et al. ${ }^{[12]}$ applied curettage grafting to the chondroblastoma of the talus of a 22-year-old male patient and did not report recurrence at two-year follow-up. In our case series, the mean age of three chondroblastoma cases with talus localization was 19 (range, 13 to 27) and the mean follow-up period was 63 (range, 25 to 134) months. We applied curettage and grafts to all three patients, and recurrence occurred in one patient during follow-up. While no recurrence was observed 
in chondroblastoma case reports in the literature, one patient who underwent curettage and grafting in this study relapsed in the follow-up. We attribute this to the short follow-up periods in the literature, while the patient in this study relapsed later (66 months).

There are publications about talus-located osteochondromain the literature. ${ }^{[13,14]}$ In the study of Ozturk et al. ${ }^{[13]}$ excision was performed in talus localized osteochondroma patients with a mean age of 32 years, and no recurrence was observed in their follow-up. Atik et al. ${ }^{[14]}$ performed excision of the talus osteochondroma of a 21-year-old male patient and reported a good clinical result. Similarly, in our study, we performed excision in two osteochondroma cases aged 7 and 67 years and we did not see recurrence.

Acrometastases are extremely rare and constitute $0.3 \%$ of all bone metastases. ${ }^{[15]}$ The os calcis was involved in $23 \%$ of the tarsal lesions, while talus was involved in $8 \%$. Most acrometastases are caused by lung, breast, bladder, and gastrointestinal system. ${ }^{[16]}$ In this study, patients with metastases localized in the talus were patients with lung and bladder cancer metastases.

There were some limitations of this study. First was the study's retrospective design. In addition, functional and clinical scores could not be given due to the different tumor types. On the other hand, although there are case reports in the literature on talus-localized lesions, studies on this subject are very limited, which is why we consider this study valuable.

In conclusion, the talus is a rare location for tumors, but benign and malignant tumors and tumorlike lesions may be localized in the talus. Although rare, talus lesions should be kept in mind in patients presenting with pain and antalgic gait.

\section{Declaration of conflicting interests}

The authors declared no conflicts of interest with respect to the authorship and/or publication of this article.

\section{Funding}

The authors received no financial support for the research and/or authorship of this article.

\section{REFERENCES}

1. Bakotic B, Huvos AG. Tumors of the bones of the feet: the clinicopathologic features of 150 cases. J Foot Ankle Surg 2001;40:277-86.

2. Dominic KP, Dijoe D, Manathara LT. Tumour like lesions and their management: a retrospective study. Int J Res Orthop 2018;4:159-65.

3. Kakhki VR, Anvari K, Sadeghi R, Mahmoudian AS, Torabian-Kakhki M. Pattern and distribution of bone metastases in common malignant tumors. Nucl Med Rev Cent East Eur 2013;16:66-9.

4. Erlemann R, Jundt G. Tumor-like lesions of bone. Radiologe 2016;56:507-19.

5. Dhillon MS, Singh B, Singh DP, Prabhu V, Nagi ON. Primary bone tumors of the talus. J Am Podiatr Med Assoc 1994;84:379-84.

6. Bell SW, Young PS, Mahendra A. Primary bone tumours of the talus: the Scottish Bone Tumour Registry experience. Foot Ankle Surg 2012;18:277-82.

7. Sharma S, Gupta P, Sharma S, Singh M, Singh D. Primary aneurysmal bone cyst of talus. J Res Med Sci 2012;17:1192-4.

8. Vosoughi AR, Mozaffarian K, Erfani MA. Recurrent aneurysmal bone cyst of talus resulted in tibiotalocalcaneal arthrodesis. World J Clin Cases 2017;5:364-7.

9. Sharma S, Wani IH, Gupta N, Mahajan N, Salaria AQ. Giant cell tumor of talus: a case report. Cases J 2009;2:74.

10. El-Moatasem el-HM, Abdel-Rahman M, Eid MA. Extended curettage and adjuvant therapy for benign tumors of the talus. Foot (Edinb) 2015;25:79-83.

11. Ningegowda RV, Subramanian K, Suresh I. Chondroblastoma of the talus. J Foot Ankle Surg 2013;52:673-7.

12. Zhang K, Gao Y, Dai H, Zhang S, Li G, Yu B. Chondroblastoma of the talus: a case report and literature review. J Foot Ankle Surg 2012;51:262-5.

13. Öztürk R, Atalay İB, Yapar AE, Beltir G, Arıkan ŞM, Güngör BŞ. Talus localized osteochondromas: Treatment management and mid-term outcomes - Case series. Eklem Hastalik Cerrahisi 2019;30:309-15.

14. Atik OŞ. What are the expectations of an editor from a scientific article? Jt Dis Relat Surg 2020;31:597-8.

15. Zindrick MR, Young MP, Daley RJ, Light TR. Metastatic tumors of the foot: case report and literature review. Clin Orthop Relat Res 1982;(170):219-25.

16. Kouvaris JR, Kouloulias VE, Papacharalampous $\mathrm{XN}$, Koutselini HA, Gennatas CS, Limouris GS, et al. Isolated talus metastasis from breast carcinoma: a case report and review of the literature. Onkologie 2005;28:141-3. 